\title{
Synthesis and aggregation behaviour of symmetric glycosylated bolaamphiphiles in water
}

\author{
Ange Polidori*, Michel Wathier, Anne-Sylvie Fabiano, Blandine Olivier, \\ and Bernard Pucci* \\ Laboratoire de Chimie Bioorganique et des Systèmes Moléculaires Vectoriels. \\ University of Avignon, 33 Rue Louis Pasteur , 84000 Avignon - France \\ E-mail: bernard.pucci@univ-avignon.fr
}

\begin{abstract}
This work is dedicated to the Professor Armand Lattes for his great contribution to the organic and supramolecular chemistry
\end{abstract}

\begin{abstract}
The synthesis of a new family of symmetric bolaamphiphiles derived from tris(hydroxymethyl)aminomethane (Tris) is described. The specific glycosylation of Tris hydroxyl groups allows modulation of their polar head volumes. Symmetric bolaamphiphiles were prepared by grafting the Tris moieties onto a hydrophobic chain through urea or amide bonds and a glycyl linker. Moreover, the introduction of phenyl groups or a perfluoroalkyl chain afforded increased rigidity of the hydrophobic spacer arm. A diluted water suspension of these amphiphiles did not show a supramolecular organisation any larger than micellar-type aggregates
\end{abstract}

Keywords: Bolaamphiphile, vesicles, micelles, aggregation behavior, supramolecular chemistry

\section{Introduction}

Bolaamphiphilic compounds consist of a hydrophobic chain with two polar head groups at its extremities. ${ }^{1}$ By virtue of their chemical structure, these compounds can form monolamellar membranes, vesicles or fibrous organisations in aqueous solution. These synthetic surfactants are in fact a copy of the lipids which form the cytoplasmic membranes of the archaebacteria, microorganisms which live in extreme conditions of temperature, pressure or $\mathrm{pH}^{2,3}$ In order to withstand these extreme living conditions, the hydrophobic chains which form the lipid bilayer of their cell membranes are fused, creating macrocyclic molecules not easily synthesised in a

\footnotetext{
${ }^{*}$ Corresponding author. Tel.: 33-4-90-14-44-42; fax: 33-4-90-14-44-49; e-mail: bernard.pucci@univ-avignon.fr, ange.polidori@univ-avignon.fr
} 
laboratory. ${ }^{4}$ For 30 years, the scientific community has been trying to synthesise lipid analogues capable of forming non-merging vesicle membranes. From this point of view, considering the slower rate of the membrane fusion phenomenon in monolamellar membranes, the bolaform surfactants represent a good alternative and archaeal membranes have begun to be used in the pharmaceutical preparation of liposomes. ${ }^{5}$

In the past 20 years, many papers have been published on this subject and numerous simplified models of archaeal lipid molecules have been synthesised. ${ }^{6}$ Indeed, the preparation of these macrocyclic molecules is a real challenge for chemists. In most cases, chemists contented themselves with preparing molecules consisting of only one hydrocarbon chain ended with polar heads. These monostrand compounds often formed fibrous networks in aqueous solution, due to the setting up of intermolecular hydrogen bonds within the membranes. ${ }^{7-13}$ On the other hand, few examples were reported describing the formation of vesicle systems by bolaform surfactants. One of the main concerns in the formation of monolamellar vesicle systems from bolaform surfactants is the nature of the spacer arm and its ability to not fold up again (figure 1).

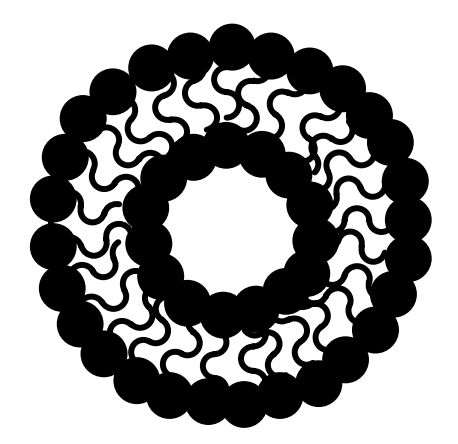

Monolamellar Vesicle

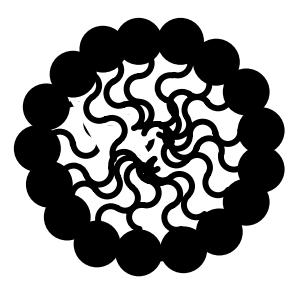

micelle

Figure 1. Structures of micelles and vesicles formed by bolaamphiphiles in aqueous solution.

Munoz et $a l^{14}$ and Brisset et $a l^{15}$ reported a significant impact of the length of the hydrophobic linkage on the aggregation properties of bolaamphiphiles with crown ether or sugar heads. These authors suggested a bending of chains consisting of 12 methylene groups or more. The aim of the work presented here is to specify the impact of various structural parameters, the length and rigidity of the hydrophobic chain and/or volume of the two polar heads, on the ability of monostrand bolaform surfactants to form vesicle-type or fibrous-type supramolecular organisations in aqueous solution. In order to modulate these different structural parameters, Tris(hydroxymethyl)aminomethane (Tris) was chosen as starting material. 


\section{Results and Discussion}

Tris is the basic component of the polar heads of these new bolaform compounds. The use of such a polyfunctional molecule permits modulation of the HLB (Hydrophilic Lipohilic Balance) of bolaamphiphiles by the grafting one, two or three galactopyranose moieties onto its hydroxyl groups. The hydrophilic head groups were linked to a hydrocarbon chain through urea or amide bonds and a glycyl linker. The Tris amine function ensures the junction with the hydrophobic component (scheme 1).
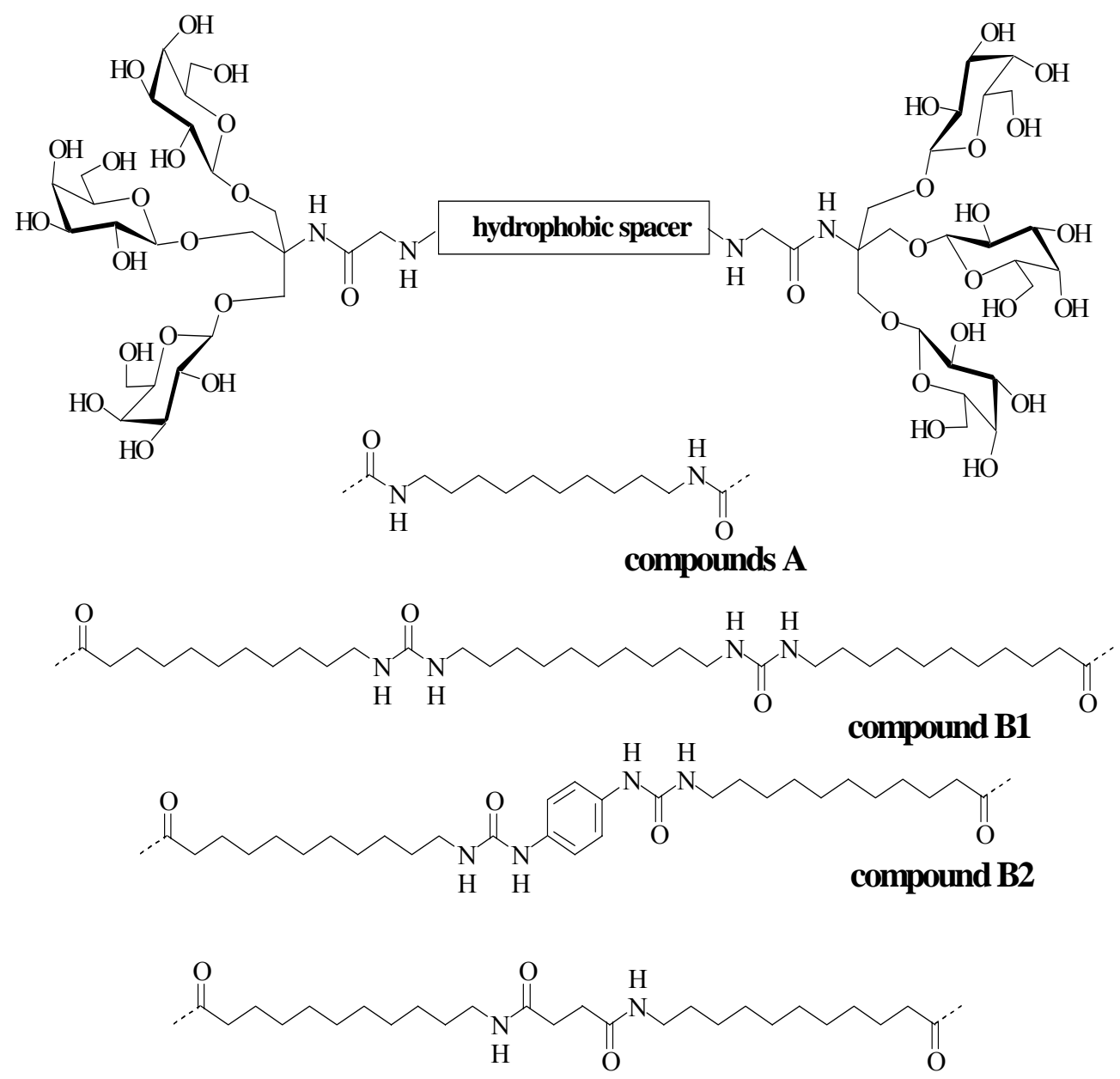

compound B3

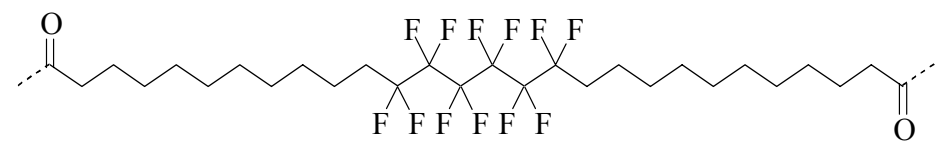

Hydrophobic spacers

compound B4

Scheme 1. Structure of Tris bolaamphiphile compounds 
In order to determine the impact of the hydrophobic linker on the aqueous behaviour of these new bolaamphiphiles, we used different alkyl chain lengths, bearing 10 to 30 carbon atoms (type-A compounds and compounds B1, B3). We tried to rigidify the hydrophobic portion by including a phenyl group (compound B2) or a perfluorocarbon chain (compound B4). Such rigid moieties should theoretically inhibit the bending of the chain.

\section{Synthesis of type-A and type-B compounds}

The glycosylated polar heads 1-3 were synthesised according to a general procedure (scheme 2) previously described. ${ }^{16}$
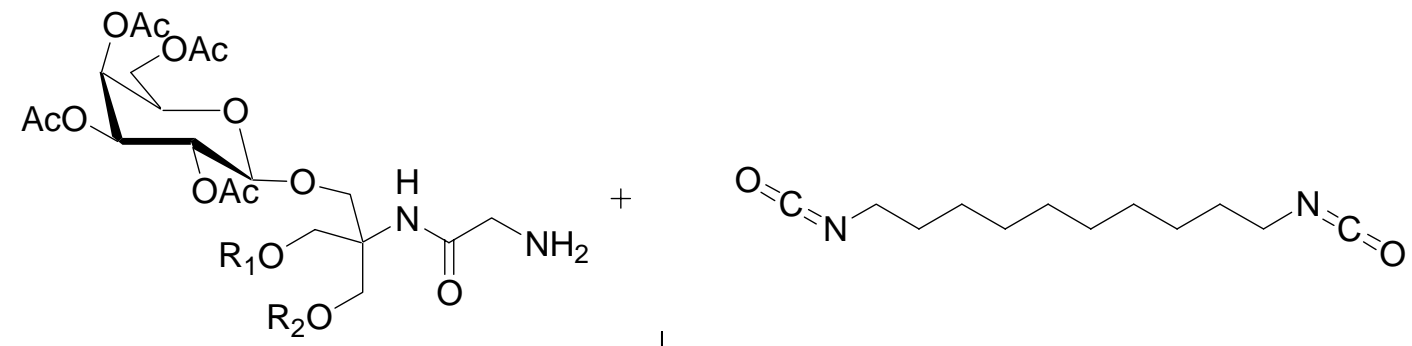

1: $\mathrm{R}_{1}=\mathrm{R}_{2}=\mathrm{H}$

2: $\mathrm{R}_{1}=\mathrm{H} ; \mathrm{R}_{2}=\mathrm{Gal}(\mathrm{OAc})_{4}$

3: $\mathrm{R}_{1}=\mathrm{R}_{2}=\mathrm{Gal}(\mathrm{OAc})_{4}$

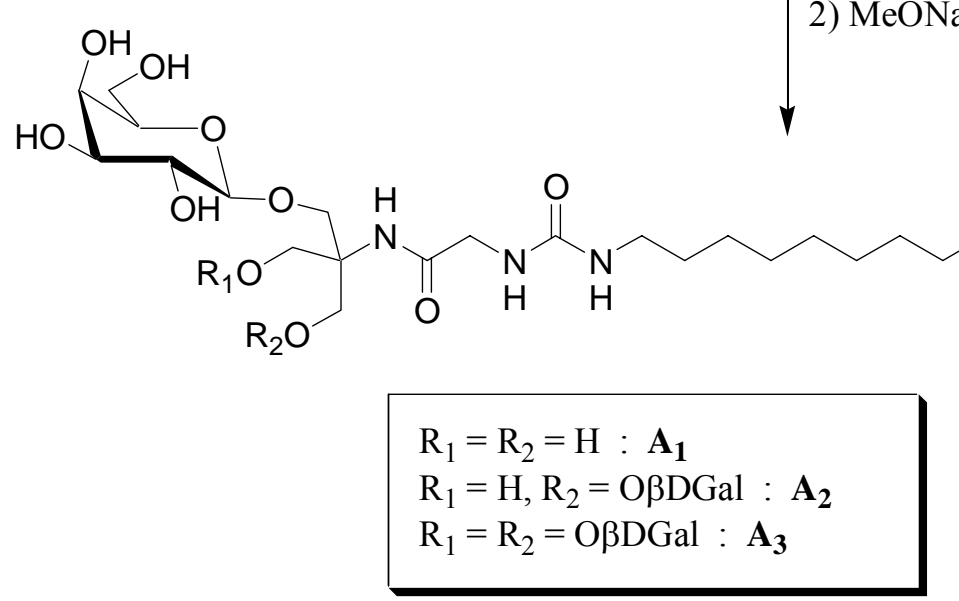

1) Toluene $/ \Delta$

2) $\mathrm{MeONa} / \mathrm{MeOH}$

Scheme 2. Synthesis of tupe A compounds

Commercially available 1,10-diisocyanate was chosen as a hydrophobic linker of type-A compounds in order to avoid bending of the chain as previously described by Brisset et al. ${ }^{15}$ The grafting of the diisocyanate and polar portions was achieved in dry toluene at room temperature in the presence of catalytic amounts of diazabicyclooctane (DABCO). This reaction produced the final A-type compounds in yields ranging from 50 to $80 \%$ after column chromatography on silica gel. Compounds B1-B3 were synthesized in 4 steps (Scheme 3). 


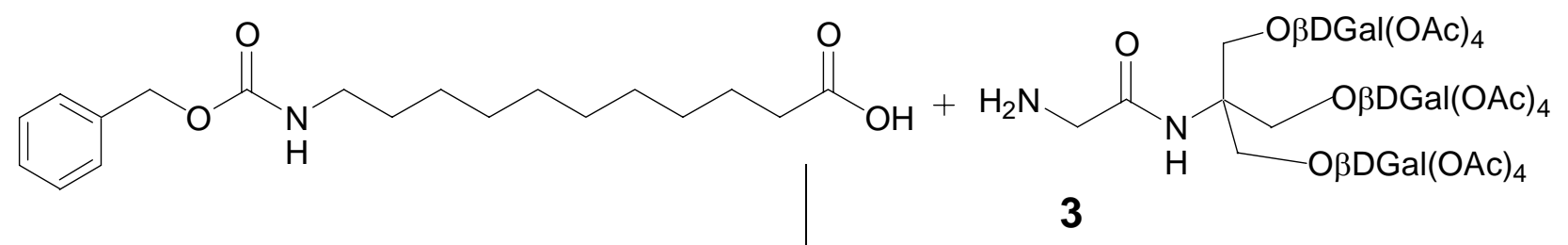

$a, b)$

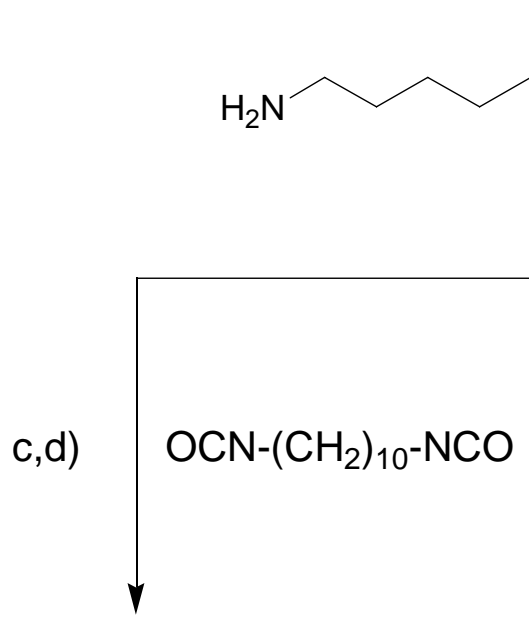

B1 $c, d)$

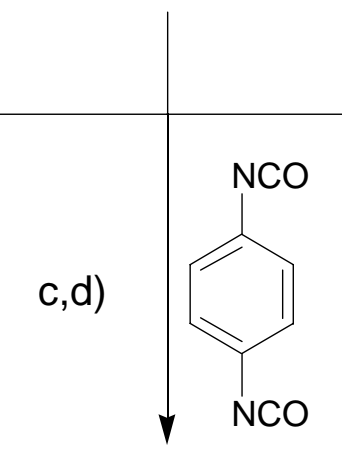

4

B2<smiles>O=C1CCC(=O)O1</smiles>

B3

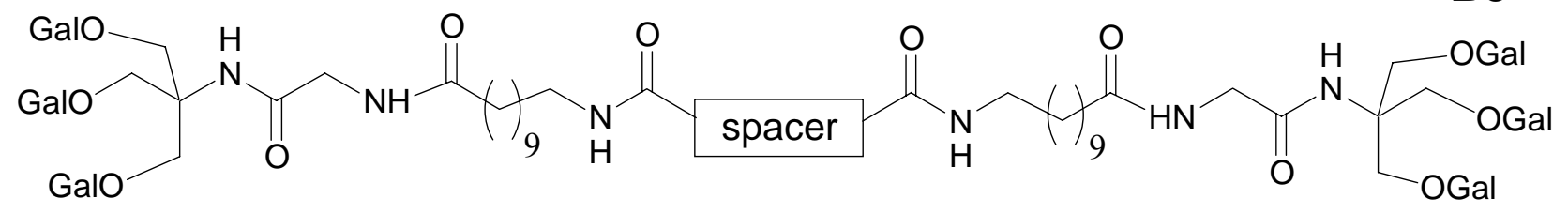

spacer : NH- $\left(\mathrm{CH}_{2}\right)_{10}-\mathrm{NH}$ : compound B1 spacer : $\mathrm{NH}-\mathrm{C}_{6} \mathrm{H}_{4}-\mathrm{NH}$ : compound $\mathbf{B} 2$ spacer : $\mathrm{CH}_{2}-\mathrm{CH}_{2}$ : compound $\mathbf{B} 3$

a) $\mathrm{DCC} / \mathrm{HOBT}$; b) $\mathrm{Pd}-\mathrm{C} / \mathrm{EtOH} / \mathrm{H}_{2}$; c) toluene/DABCO/diisocyanate or succinic anhydride/DCC ; d) $\mathrm{MeONa} / \mathrm{MeOH}$

Scheme 3. Synthesis pathway of Tris hydrocarbon B-type bolaamphiphiles

The reaction of benzyloxycarbonyl-amino-11-undecanoic acid with compound $\mathbf{3}$ was catalyzed by a mixture of dicyclohexylcarbodiimide and dimethyl aminopyridine (DDC/DMAP). Subsequent hydrogenation on palladium on charcoal $(\mathrm{Pd} / \mathrm{C})$ provided the deprotected synthon 4. Decyl diisocyanate and phenyl diisocyanate were then treated with an excess of synthon $\mathbf{4}$ in toluene to give acetylated bolaamphiphiles B1 and B2 in a good overall yield (30-38\%). Reaction of synthon 2 with succinic anhydride, in the presence of DCC/DMAP as coupling reagent, provided compound B3 with an overall yield of $23 \%$. Pure compounds B1-B3 were 
obtained after silica-gel column chromatography and sephadex LH-20 using a mixture of dichloromethane-methanol as an eluent.

The fluorinated bolaamphiphile B4 was prepared in five steps (scheme 4).
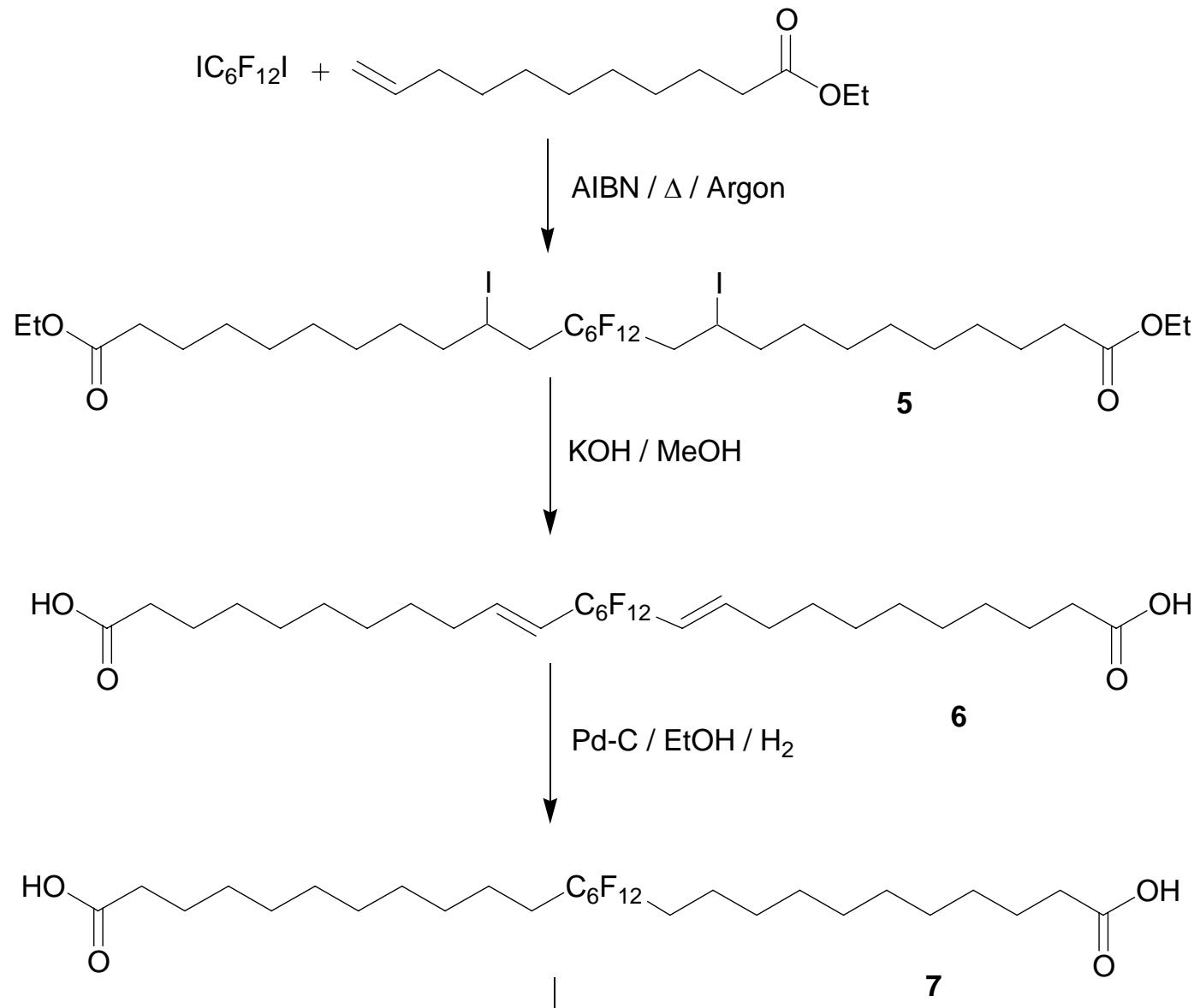

a) DCC / HOBT / compound $1 / \mathrm{CH}_{2} \mathrm{Cl}_{2}$

b) $\mathrm{MeONa} / \mathrm{MeOH}$

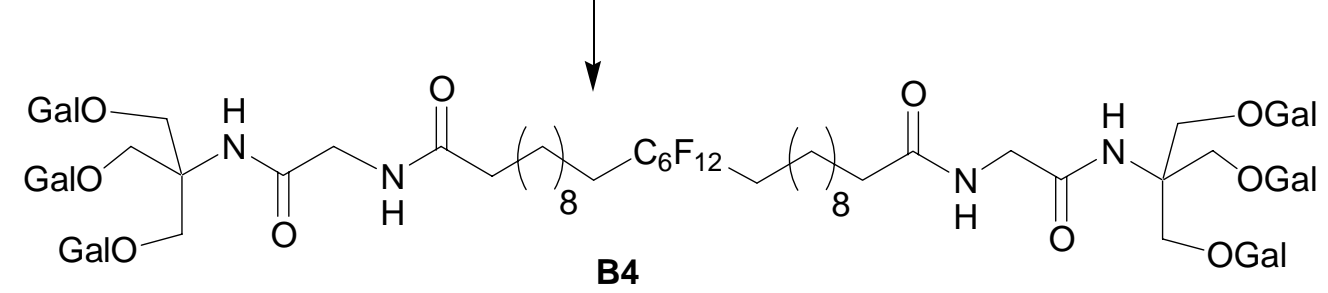

Scheme 4. Synthesis pathway of Tris fluorocarbon bolaamphiphiles.

First, we carried out a free radical condensation of 1,6-diiodoperfluorohexane on ethyl 11undecenoate as previously described by Brace. ${ }^{17}$ The fluorinated compound 5 thus obtained was treated with potassium hydroxide in methanol to give the diacid $\mathbf{6}$. We obtained a mixture of cis (25\%) and trans $(75 \%)$ isomers, detected by $\mathrm{H}^{1}$ NMR. Compound 6 was then hydrogenated on 
$\mathrm{Pd} / \mathrm{C}$ in ethanol. The diacid $\mathbf{7}$ thus obtained reacted with synthon $\mathbf{1}$ in the presence of DCC/DMAP as a coupling reagent, with a low yield (23\%). The type-A and B bolaamphiphiles were deacetylated according to the Zemplen method, by transesterification in methanol with a catalytic amount of sodium methoxide. All compounds were isolated after gel filtration on sephadex G-25, freeze-dried and were fully characterized by NMR spectroscopy and mass spectroscopy (see experimental section).

\section{Aggregation properties of Tris derived bolaamphiphiles}

The physico-chemical features and aggregation properties of these compounds are summarised in Table 1. Dilute dispersions of all these compounds were obtained by vortex mixing at $50^{\circ} \mathrm{C}$ and sonication for $10 \mathrm{~min}$ at $25{ }^{\circ} \mathrm{C}$ using a $3 \mathrm{~mm}$ probe. They were then studied by Transmission Electron Microscopy (TEM), after negative staining with uranyl acetate, and Freeze-Fracture Electron Microscopy (FFEM). The critical aggregation concentrations (CAC) were determined either by measuring their superficial tension vs concentration, or by the dye method in spectrofluorimetry (with pyrene) or in colorimetry, according to Menger's method with pinacyanol chloride. ${ }^{18}$

Table 1. Physico-chemical data of compounds A-B

\begin{tabular}{|c|c|c|c|c|c|c|}
\hline Entries & $\begin{array}{l}\text { Overall } \\
\text { yield } \%\end{array}$ & $\begin{array}{l}\mathrm{F}^{(1)} \\
\left({ }^{\circ} \mathrm{C}\right)\end{array}$ & {$[\alpha]_{D}^{20(1)}$} & $\begin{array}{l}\mathrm{CAC}^{3} \\
(\mathrm{mM})\end{array}$ & $\begin{array}{c}\text { Aggregate } \\
\text { diameter } \\
(\mathrm{nm})\end{array}$ & $\begin{array}{c}\text { Aggregati } \\
\text { on } \\
\text { State }^{4}\end{array}$ \\
\hline A1 & 22 & 63 & $-2.2^{\circ}$ & ND & & - \\
\hline A2 & 22 & 90 & $-10.1^{\circ}$ & 50 & & - \\
\hline A3 & 28 & 102 & $-10.4^{\circ}$ & ND & & - \\
\hline B1 & 38 & 88 & $-8.3^{\circ}$ & 0.066 & 9 & micelles \\
\hline B1cs ${ }^{22}$ & & & & $0.013^{5}$ & & \\
\hline B2 & 30 & 83 & $-7.1^{\circ}$ & $\mathrm{ND}^{2}$ & & micelles \\
\hline B3 & 23 & 101 & $-9.3^{\circ}$ & 1.2 & & micelles \\
\hline B3cs ${ }^{21}$ & & & & $1^{5}$ & & \\
\hline B4 & 6 & 96 & $-10.7^{\circ}$ & 0.0049 & 6.8 & micelles \\
\hline
\end{tabular}

${ }^{1}$ Acetylated compounds ${ }^{2}$ Not Determined ${ }^{3}$ Determined by pyrene method ${ }^{4}$ Determined by ffem ${ }^{5}$ Determined by surface tension measurement

Type A compounds bearing a ten carbon atom hydrophobic portion did not show any visible objects on the images obtained by FFEM, regardless of the number of galactosylated units grafted on the polar head (figure not shown). This observation indicates the absence of supramolecular organisations larger than very small micelle-like aggregates. 

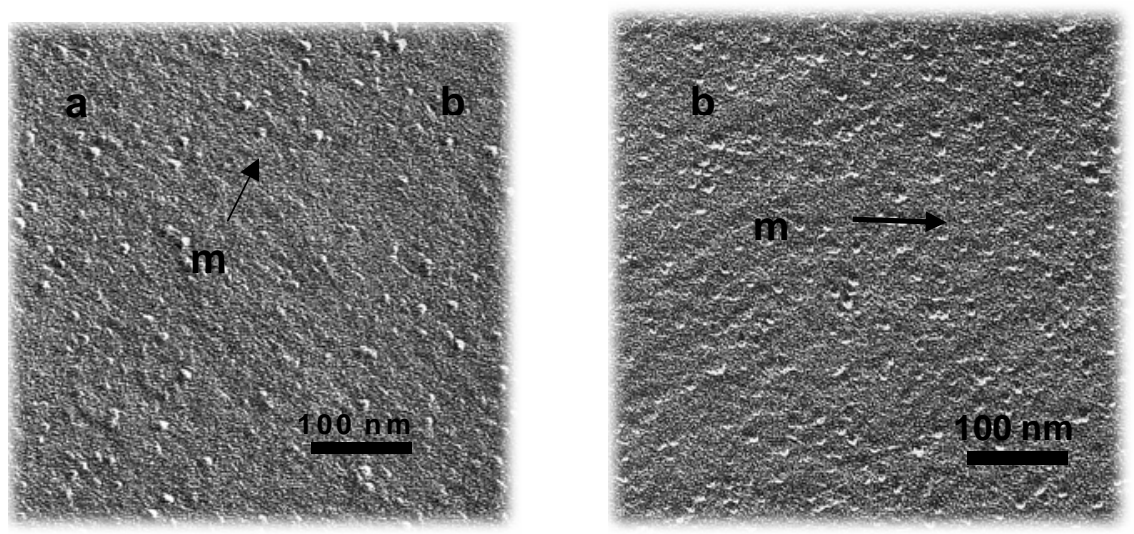

Figure 2. Electron micrographs after freeze-fracture of compound $\mathbf{B 1}$ at $100 \mathrm{mg} / \mathrm{ml}$ (a) and compound $\mathbf{B} 4$ at $100 \mathrm{mg} / \mathrm{ml}$ (b) in water.

It should be emphasized that the micrographs obtained by TEM, after negative staining by uranyl acetate, showed vesicle-like aggregates, at variance with the FFEM results (picture not shown). This result reveals a difficulty in properly analyzing supramolecular organisations by TEM alone; in many cases artifacts were observed. Thus, all results obtained by TEM should be confirmed with other techniques such as FFEM or cryoTEM.

Apparently, for short hydrophobic spacers, the HLB does not play a key role on the aggregation behaviour of these bolaamphiphilic compounds. It seems that the hypothesis of the impact of the spacer length previously proposed can not be applied to all kinds of bolaform surfactants. $^{14,15}$ The formation of unilamellar vesicles (ULV) from mono-strand surfactants seems to depend on other parameters than spacer length.

Thus, in order to specify the association ability of these compounds in aqueous solutions, we tried to highlight and measure their possible critical aggregation concentration. The surface tension measurements did not allow us to determine a CAC up to $0.1 \mathrm{M}$. Indeed, with this method, equilibrium surface tension values were difficult to obtain. The CAC determinations performed with compound A2, showed an atypical behaviour with the dye methods (figure 3), quite different from other surfactants. ${ }^{18}$ Indeed, if an aqueous solution of pinacyanol chloride containing, for example, the perfluorocarbon bolaform surfactant presented a constant absorbance up to the Critical Micellar Concentration (CMC) at $610 \mathrm{~nm}$ and a marked decrease of the absorbance below the $\mathrm{CMC}$, one observed a continuous decrease of the absorbance vs dilution with the bolaform surfactant A2. One can assume that, unlike the micelle-like aggregates which fully dissociated at concentrations lower than the $\mathrm{CMC}$, compound $\mathbf{A} 2$ aggregates broke up slowly upon dilution. 


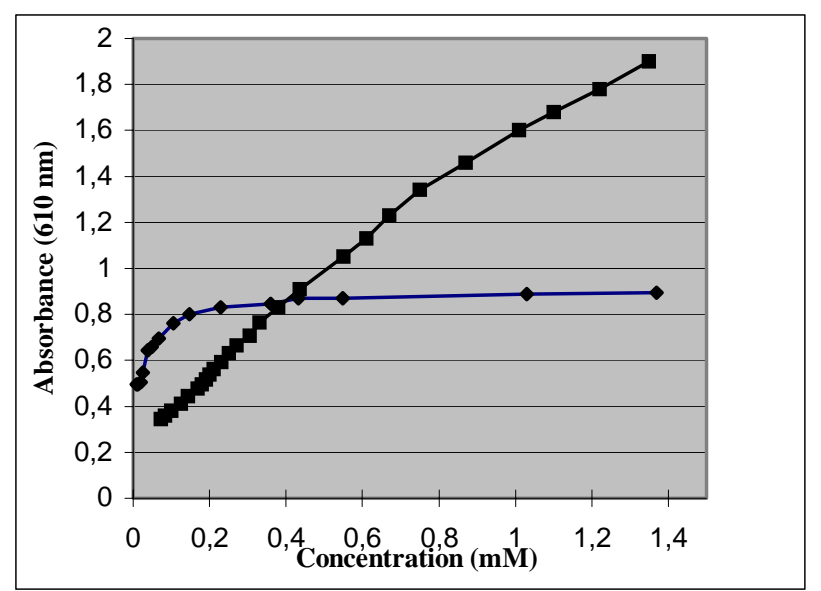

Figure 3. Plot of the absorbance of $1.10^{-5} \mathrm{M}$ pinacyanol chloride at $610 \mathrm{~nm}$ versus concentration of fluorinated B4 $(\bullet)$ and hydrocarbon A2 ( $\mathbf{a})$ bolaamphiphile.

The critical micelle concentration of compound A2 was also determined by spectrofluorimetry with pyrene as a probe (figure $4 \mathrm{a}$ ). The fluorescence emission spectra were obtained with aerated solutions at very low pyrene concentration $\left(2.10^{-6} \mathrm{M}\right)$ at an excitation wavelength of $335 \mathrm{~nm}$. The spectra were used to specify the $I_{1} / I_{3}$ ratio of the intensities of the first and third vibronic peaks of pyrene monomer. The $I_{1} / I_{3}$ ratio is sensitive to the microenvironment of pyrene and can be used to highlight any change in polarity sensed by the pyrene probe while, upon micelle or aggregate formation, the pyrene probe becomes partly or totally solubilised within the aggregates. The change of $\mathrm{I}_{1} / \mathrm{I}_{3}$ ratio vs surfactant concentration can thus be used to obtain the CMC of bolaamphiphilic compounds. The CAC values were determined at the point of the initial break in the $I_{1} / I_{3}$ value vs $\log C$ curve (figure $4 a$ ).

This very sensitive procedure allowed us to measure a CAC for the compound A2 (5.10 ${ }^{-2}$ $\mathrm{M})$. Thus, we observed a gradual decline in the $\mathrm{I}_{1} / \mathrm{I}_{3}$ ratio after the initial drop was reached, meaning a slow equilibrium in aggregate formation.

The increase in the number of methylene groups (compounds B1 and B3) or the insertion of phenyl groups or fluor atoms into the hydrophobic chain (compounds B2 and B4) led to the formation of small (less than $100 \AA$ ) monodisperse particles at high concentration $(100 \mathrm{mg} / \mathrm{ml})$, as observed by FFEM (figures $2 \mathrm{a}$ and $2 \mathrm{~b}$ ). This type of freeze fracture image was in good agreement with the presence of micelles. The surface density of these particles was proportional to the concentration of the compounds. Indeed, dilution of the solutions resulted in a strong decrease in micelle density. 



Figure 4. Variation of pyrene monomere fluorescence $I_{1} / I_{3}$ ratio in water as a function of $\mathbf{A} 2$ (a), B4 (b), B3 (c) and B1 (d) concentration.

Thus, we measured the CMC of some representative compounds of these surfactants by the pyrene method. ${ }^{19}$ The relative CMC values were coherent. The compound B3 (figure 4c), having 20 methylene groups in the spacer arm, exhibited a CMC (1.2 mM) 20 times higher than compound B1 $(0.066 \mathrm{mM})$, in which the hydrophobic chain included 30 methylene groups (figure 4d).

Due to the high hydrophobicity of perfluorocarbon chains, fluorinated compound B4 presented a CMC (0.0049 mM) 10 times lower than B1 (figure 4b). It is generally acknowledged that a $\mathrm{CF}_{2}$ group is roughly 1.7 times more hydrophobic than a $\mathrm{CH}_{2}$ group. ${ }^{20}$ Furthermore, we observed that the CMC of compound B3 is very close to that of its analogous surfactant B3cs (1 $\mathrm{mM}$ ), bearing a dodecylthioether chain as the hydrophobic component (figure 5). 


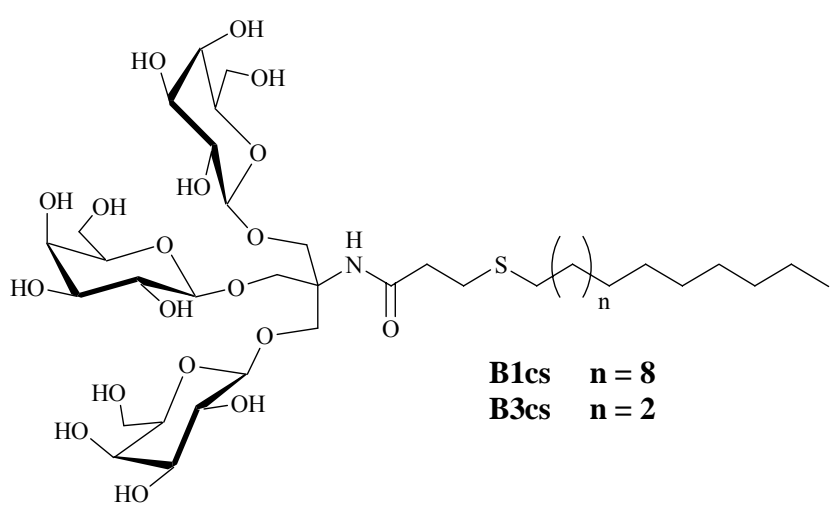

Figure 5. Structure of B1cs and B3cs compounds

In the same way, compounds B1 and B1cs, bearing a hexadecylthioether chain, exhibited comparable Critical Micellar Concentrations, $0.066 \mathrm{mM}$ and $0.013 \mathrm{mM}$, respectively (the synthesis and physico-chemical properties of surfactants B1cs and B3cs were previously reported. ${ }^{21}$ Such results are in very good agreement with the hypothesis that the hydrophobic segment folds up when bolaform surfactants bear a long hydrocarbon spacer arm. ${ }^{14,15}$ However, it is noteworthy that the rigidity of the linker in compounds $\mathbf{B} 2$ and $\mathbf{B 4}$, afforded by a biphenyl or fluorocarbon chain, did not prevent micelle formation and thus, probably, the folding up of the spacer group.

\section{Conclusions}

The preliminary results reported here show that synthetic bolaforms derived from a polyol, such as a Tris moiety, are not good candidates for vesicle formation whatever the length or the rigidity of the spacer arm. The insertion of a short hydrophobic linker between the two polar heads (typeA compounds) did not lead to vesicle or membrane systems. Such bolaform surfactants formed atypical associations which did not look like classic micellar systems. These compounds were probably unable to form micelles by a suitable folding up of their hydrophobic chain, because of their short hydrophobic segments. The accurate nature of the aggregates they formed will have to be determined by other physico-chemical techniques. The lengthening of the hydrophobic linker led to its folding up and the formation of spherical micelles, which could be studied by the FFEM technique. An increase in the rigidity of the hydrophobic linker arm, through the introduction of phenyl groups or a perfluorocarbon chain, did not prevent the folding up phenomenon. It seems that monostrand bolaform surfactants are not able to form unilamellar membrane vesicles. The most suitable and easiest means to form vesicles now seems to be the use of acyclic doublestrand bolaform surfactants. These are easily synthesised by grafting a lateral hydrophobic chain close to the polar heads (Figure 6). Such a method was successfully carried out by Guilbot et al. ${ }^{22}$ 


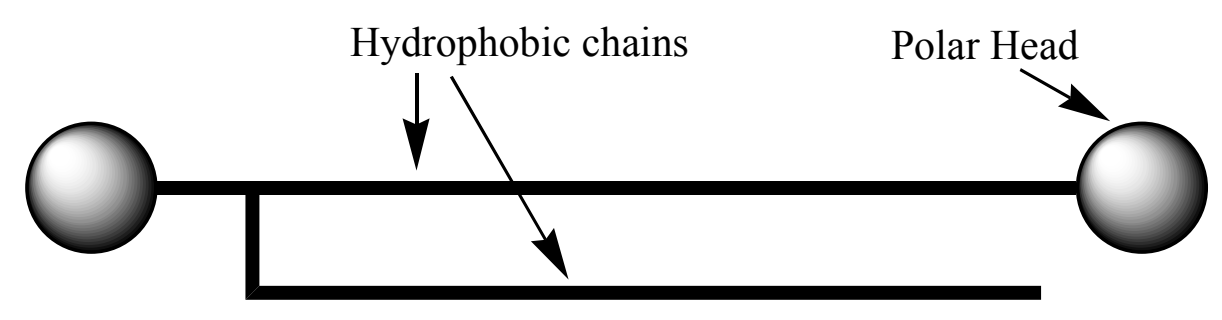

Figure 6. General structure of biantennary bolaamphiphiles according to Guilbot et al. ${ }^{22}$

\section{Experimental Section}

General Procedures. The progress of the reactions and the homogeneity of the compounds were monitored by thin layer chromatography (TLC Merck 254). Compound detection was achieved by exposure to UV light $(254 \mathrm{~nm})$, by spraying a $5 \%$ sulfuric acid solution in methanol, or 5\% ninhydrin solution in ethanol (in order to detect the amine-containing compound), then heating at $150^{\circ} \mathrm{C}$. Purifications were achieved by column chromatography over silica gel (Merck 60). Melting points were measured on an electrothermal machine and have not been corrected. The ${ }^{1} \mathrm{H}$ NMR, ${ }^{13} \mathrm{C}$ NMR and ${ }^{19} \mathrm{~F}$ NMR spectra were recorded using a BRUKER AC 250 at a frequency of $250 \mathrm{MHz}$ for ${ }^{1} \mathrm{H}, 62.86 \mathrm{MHz}$ for ${ }^{13} \mathrm{C}$ and $235 \mathrm{MHz}$ for ${ }^{19} \mathrm{~F}$ spectra. The spectrum settings of the glycosylated compounds were taken from the acetylated compounds before deprotection (in $\mathrm{CDCl}_{3}$ ), as this facilitates taking a reading. Chemical shifts are given in ppm relative to tetramethylsilane using the deuterium signal of the solvent $\left(\mathrm{CDCl}_{3}\right)$ as a heteronuclear reference for ${ }^{1} \mathrm{H}$ and ${ }^{13} \mathrm{C}$. For the ${ }^{19} \mathrm{~F}-\mathrm{NMR}$ spectra, the internal reference is $\mathrm{CFCl}_{3}$. Mass spectra were recorded on a DX 300 Jeol apparatus. Sonication was performed by pulsing (power 100\%) with a titanium probe, $3 \mathrm{~mm}$ in diameter, on a Vibracell sonicator 72412. Reactions were carried out in anhydrous conditions under dry nitrogen. All the solvents were distilled and dried according to standard procedure.

Preparation of aqueous suspensions. Type A and B compounds were dispersed in deionized water $(10 \mathrm{mg} / \mathrm{ml})$ as a following procedure. The compound was dissolved in methanol and the solvent removed under vacuum. The thin film obtained was thus dispersed in deionized water and stirred with a vortex for $5 \mathrm{~min}$. Then the dispersion was sonicated for $15 \mathrm{~min}$ (titanium probe of $3 \mathrm{~mm}$, power $40 \%, 1 / 1$ pulse method).

Identification of vesicles by Transmission Electron Microscopy and freeze-fracture electron microscopy. The formation of vesicles was observed by Transmission Electron Microscopy (TEM) according to the negative staining method and by Freeze fracture Electron Microscopy (FFEM) as previously described. ${ }^{23}$ The samples were examined using a Philips CM 10 microscope (TEM) or a Zeiss EM 912 electron microscope (Zeiss, Iena, Germany) (FFEM).

Steady-state fluorescence measurements. Fluorescence spectra were obtained on a SPEXFluoromax 2 instrument from Jobin Yvon. Emission spectra were taken at an excitation 
wavelength of $338 \mathrm{~nm}$ with a band-pass of $4 \mathrm{~nm}$. $\mathrm{I}_{1} / \mathrm{I}_{3}$ values obtained from emission spectra were reproducible within 0.02 . Pyrene was used as a probe at the very low concentration of $1-2$ $\mathrm{mM}$ which ensures the absence of excimer. This ratio is sensitive to the microenvironment of pyrene. The decline of the I1/I3 ratio with surfactant concentration corresponds to the beginning of the aggregation process. The solutions were prepared as follows: to a series of dry flasks were added aliquots of a methanol solution of pyrene. A thin layer of dye was formed in each flask after the solvent was evaporated in a stream of nitrogen. Surfactant solutions of different concentrations were added and the probe was solubilised in the resulting solutions in an ultrasonic bath. The solutions were stabilised for $12 \mathrm{~h} 00$ before the fluorescence measurements were made.

Pinacyanol chloride absorption. A glass cuvette was filled with $3 \mathrm{ml}$ of a $1.0310^{-5} \mathrm{M}$ pinacyanol chloride solution in distilled water. Small volumes of bolaamphiphiles solution were injected into this solution with a micropipette to obtain the desired concentration. The mixture was stirred with a vortex mixer and rested $5 \mathrm{~min}$ before measuring the absorption at $610 \mathrm{~nm}$ using a Spectronic 20D+ (Milton Roy Company) spectrophotometer.

\section{Compound characterization}

Compound A1. 1,10-decanediisocyanate ( $82 \mathrm{mg}, 0.36 \mathrm{mmole})$, DABCO (20 $\mathrm{mg})$ and compound 1 (500 mg, $0.83 \mathrm{mmole})^{21}$ were stirred at room temperature in dry toluene for $8 \mathrm{~h} 00$. The solution was concentrated under vacuum and the residue directly applied at the top of a silica-gel column (ethyl acetate/ acetonitrile / triethyl amine $80: 19: 1 \mathrm{v} / \mathrm{v}$ ) to afford the pure product $\mathbf{A 1}$ as an amorphous solid $\left(400 \mathrm{mg}, 60 \%, \mathrm{Mp}: 63^{\circ} \mathrm{C}\right) .[\alpha]_{\mathrm{D}}=-2.2\left(\mathrm{c}, 1, \mathrm{CH}_{2} \mathrm{Cl}_{2}\right) .{ }^{1} \mathrm{H} \mathrm{NMR}(250 \mathrm{MHz}$, $\left.\mathrm{CDCl}_{3}\right) \delta 7\left(2 \mathrm{H}, \mathrm{t}, \mathrm{NH}\right.$ tris), $5.9(2 \mathrm{H}, \mathrm{t}, \mathrm{NH}), 5.4\left(4 \mathrm{H}, \mathrm{m}, \mathrm{NH}, \mathrm{H}_{4}\right), 5.1-5.0\left(4 \mathrm{H}, \mathrm{m}, \mathrm{H}_{3}, \mathrm{H}_{2}\right), 4.5$ $\left(2 \mathrm{H}, \mathrm{d}, \mathrm{H}_{1}\right), 4.4$ (8H, m, CH2OAc), 4.2 (8H, m, $\mathrm{CH}_{2}$ tris, $\mathrm{CH}_{2}$ gly), 4.0-3.8 (6H, m, $\mathrm{H}_{5}, \mathrm{H}_{6}, \mathrm{H}_{6}$ ) $), 3.2$ $\left(4 \mathrm{H}, \mathrm{m}, \mathrm{CH}_{2} \mathrm{NH}\right), 2.2-2.0\left(36 \mathrm{H}, \mathrm{m}, \mathrm{CH}_{3} \mathrm{CO}\right), 1.5-1.3$ (16H, m, $\mathrm{CH}_{2}$ chain). ${ }^{13} \mathrm{C} \mathrm{NMR}(62.86$ $\left.\mathrm{MHz}, \mathrm{CDCl}_{3}\right) \delta$ 171.3-169.8 (CO), 158.6 (CO urea), 101.2 (C anomer $\beta$ ), 70.7-67.0 $\left(\mathrm{CH}_{2} \mathrm{gly}\right.$,

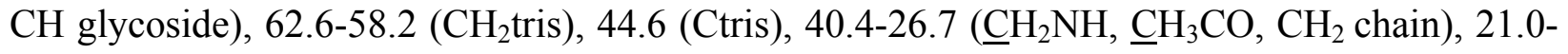
$20.5\left(\mathrm{CH}_{3}\right) . \mathrm{FAB}^{+} \mathrm{MS}: \mathrm{m} / \mathrm{z}=1409(\mathrm{M}+\mathrm{H})^{+}$.

Compound A2. Prepared according to the above procedure, starting from compound 2 (456 $\mathrm{mg}$, $0.517 \mathrm{mmole}),{ }^{16}$ DABCO (20 mg) and 1,10-decanediisocyanate (50 mg, $\left.0.225 \mathrm{mmole}\right)$, to afford compound A2 after purification by flash chromatography (ethyl acetate/acetonitrile /triethyl amine $90: 9: 1 \mathrm{v} / \mathrm{v} / \mathrm{v})$ as an amorphous solid $\left(214 \mathrm{mg}, 49 \%, \mathrm{Mp}: 90^{\circ} \mathrm{C}\right) .[\alpha]_{\mathrm{D}}=-10.1(\mathrm{c}, 1$, $\left.\mathrm{CH}_{2} \mathrm{Cl}_{2}\right) .{ }^{1} \mathrm{H} \mathrm{NMR}\left(250 \mathrm{MHz}, \mathrm{CDCl}_{3}\right) \delta 6.5(2 \mathrm{H}, \mathrm{t}, \mathrm{NH}$ tris $), 5.4\left(4 \mathrm{H}, \mathrm{d}, \mathrm{H}_{4}\right), 5.1-5.0(10 \mathrm{H}, \mathrm{m}$, $\mathrm{H}_{3}, \mathrm{H}_{2}, \mathrm{NH}$ Gly), 4.9 (2H, t, NH urea), 4.4 (4H, m, H $\mathrm{H}_{1}$, 4.2-3.7 (28H, m, $\mathrm{CH}_{2} \mathrm{Oac}_{2} \mathrm{CH}_{2}$ tris, $\left.\mathrm{CH}_{2} \mathrm{gly}, \mathrm{H}_{5}, \mathrm{H}_{6}, \mathrm{H}_{6}\right), 3.2\left(4 \mathrm{H}, \mathrm{m}, \mathrm{CH}_{3} \mathrm{NH}\right), 2.2-1.9\left(54 \mathrm{H}, \mathrm{m}, \mathrm{CH}_{3} \mathrm{CO}\right), 1.5-1.3$ (16H, m, $\mathrm{CH}_{2}$ chain). ${ }^{13} \mathrm{C}$ NMR (62.86 MHz, $\mathrm{CDCl}_{3}$ ) $\delta$ 170.8-169.8 (CO), 158.0 (CO urea), 101.4-101.2 (C anomer $\beta$ ), 70.8-68.1 (CH glycoside), 62.9-58.8 ( $\mathrm{CH}_{2}$ tris, $\mathrm{CH}_{2} \mathrm{gly}$ ), 44.3 (Ctris), 40.5-26.7

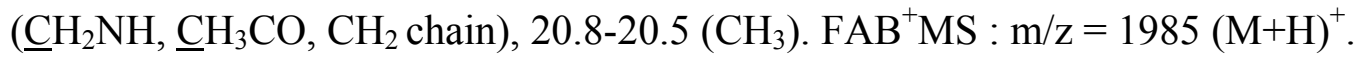

Compound A3. Prepared according to the above procedure starting from compound 3 (897 $\mathrm{mg}$, 0.765 mmole $),{ }^{16}$ DABCO $(20 \mathrm{mg})$ and 1,10-decanediisocyanate (78 $\left.\mathrm{mg}, 0.348 \mathrm{mmole}\right)$ to afford 
compound A3 after purification by flash chromatography (ethyl acetate / triethyl amine $99: 1 \mathrm{v} /$ v) as an amorphous solid (450 mg, $\left.60 \%, \mathrm{Mp}: 102^{\circ} \mathrm{C}\right) .[\alpha]_{\mathrm{D}}=-10.4\left(\mathrm{c}, 1, \mathrm{CH}_{2} \mathrm{Cl}_{2}\right)$. ${ }^{1} \mathrm{H}$ NMR $\left(250 \mathrm{MHz}, \mathrm{CDCl}_{3}\right) \delta 6.3(2 \mathrm{H}, \mathrm{t}, \mathrm{NH}$ tris $), 5.4\left(6 \mathrm{H}, \mathrm{d}, \mathrm{H}_{4}\right), 5.2-5.0\left(14 \mathrm{H}, \mathrm{m}, \mathrm{H}_{3}, \mathrm{H}_{2}, \mathrm{NH}\right.$ Gly), 4.9 ( $2 \mathrm{H}, \mathrm{t}, \mathrm{NH}$ urea), $4.4\left(6 \mathrm{H}, \mathrm{m}, \mathrm{H}_{1}\right), 4.2-3.8\left(34 \mathrm{H}, \mathrm{m}, \mathrm{CH}_{2}\right.$ tris, $\left.\mathrm{CH}_{2} \mathrm{gly}, \mathrm{H}_{5}, \mathrm{H}_{6}, \mathrm{H}_{6}\right), 3.2$ (4H, m, $\left.\mathrm{CH}_{3} \mathrm{NH}\right), 2.2-2.0\left(72 \mathrm{H}, \mathrm{m}, \mathrm{CH}_{3} \mathrm{CO}\right), 1.5-1.3\left(16 \mathrm{H}, \mathrm{m}, \mathrm{CH}_{2}\right.$ chain). ${ }^{13} \mathrm{C} \mathrm{NMR}\left(62.86 \mathrm{MHz}, \mathrm{CDCl}_{3}\right)$ $\delta 170.5$ (CO), 158.7 (CO urea), 101.3 (C anomer $\beta$ ), 70.8-59.3 ( $\mathrm{CH}$ glycoside, $\mathrm{CH}_{2}$ tris, $\mathrm{CH}_{2}$ gly), 44.0 (Ctris), 40.7-26.8 ( $\underline{\mathrm{CH}}_{2} \mathrm{NH}, \underline{\mathrm{CH}}_{3} \mathrm{CO}, \mathrm{CH}_{2}$ chain), 20.7-20.5 $\left(\mathrm{CH}_{3}\right) . \mathrm{FAB}^{+} \mathrm{MS}: \mathrm{m} / \mathrm{z}=2561$ $(\mathrm{M}+\mathrm{H})^{+}$.

Benzyloxycarbonyl amino-11-undecanoic acid. Amino-11-undecanoic acid (8.0 g, 39.0 mmoles) was stirred in a mixture of acetonitrile / water $(500 \mathrm{ml}, 50 / 50: 1 / 1)$ at $0^{\circ} \mathrm{C}$. Benzyl chloroformate $(10.15 \mathrm{~g}, 59.7$ mmoles) was added dropwise. The $\mathrm{pH}$ was adjusted to 7-8 by adding dropwise $3 \mathrm{~N} \mathrm{NaOH}$ solution. The mixture was stirred at room temperature for $24 \mathrm{~h}$ and acidified ( $\mathrm{pH} 3$ ). The precipitate was filtered and dissolved in dichloromethane, washed with water, dried with sodium sulfate and concentrated under vacuum. Pure compound $\mathbf{4}$ was obtained as a white amorphous powder after crystallization in hot ethyl acetate $(8.1 \mathrm{~g}, 62 \%)$. ${ }^{1} \mathrm{H}$ NMR $\left(250 \mathrm{MHz}, \mathrm{CDCl}_{3}\right) \delta 7.3$ (5H, m, Ph), 5.08 ( $\left.2 \mathrm{H}, \mathrm{s}, \mathrm{C}_{2} \underline{2}^{-} \mathrm{Ph}\right), 4.7$ (1H, t, NH), 3.1 ( 2H, dd, $\underline{\mathrm{C}}_{\underline{2}^{-}}$ $\mathrm{NH}), 2.4\left(2 \mathrm{H}, \mathrm{t}, \mathrm{CH}_{2}-\mathrm{CO}\right), 1.59-1.27$ (16H, m, $\mathrm{CH}_{2}$ chain). ${ }^{13} \mathrm{C} \mathrm{NMR}\left(62.86 \mathrm{MHz}, \mathrm{CDCl}_{3}\right) \delta$ 178.9 (CO), 142.1 ( $\mathrm{C}_{1}$ Phenyl), 128.4-128.1 (C Phenyl), $66.6\left(\mathrm{CH}_{2} \mathrm{NH}\right), 41.1\left(\underline{\mathrm{CH}}_{2} \mathrm{Ph}\right), 33.9-24.6$ ( $\mathrm{CH}_{2}$ chain).

Compound 4. Benzyloxycarbonyl amino-11-undecanoic acid (4.55 g, 3.9 mmoles), compound 4 (1.44 g, 4.28 mmoles), DCC (1.043 g, 5 mmoles) and DMAP ( $0.522 \mathrm{~g}, 4.28$ mmoles) were stirred in dry dichloromethane $(25 \mathrm{ml})$ at room temperature for $12 \mathrm{~h}$. The mixture was filtered and washed with $1 \mathrm{~N} \mathrm{HCl}(30 \mathrm{ml})$ and $10 \% \mathrm{NaHCO}_{3}(30 \mathrm{ml})$. Organic layer was dried with sodium sulfate and concentrated under vacuum.

The crude product was subjected to column chromatography on silicagel (ethyl acetate / hexane $85 / 15 \mathrm{v} / \mathrm{v})$ to afford the pure product 4 as a white amorphous powder $(3.6 \mathrm{~g}, 62 \%) .{ }^{1} \mathrm{H}$ NMR $\left(250 \mathrm{MHz}, \mathrm{CDCl}_{3}\right) \delta 7.4(5 \mathrm{H}, \mathrm{m}, \mathrm{Ph}), 6.34(1 \mathrm{H}, \mathrm{s}, \mathrm{NH}$ tris $), 6.2(1 \mathrm{H}, \mathrm{t}, \mathrm{NH}$ gly $), 5.3(3 \mathrm{H}$, dd, $\left.\mathrm{H}_{4}\right), 5.0\left(8 \mathrm{H}, \mathrm{m}, \mathrm{CH}_{2} \mathrm{Ph}, \mathrm{H}_{3}\right.$ et $\left.\mathrm{H}_{2}\right), 4.8\left(1 \mathrm{H}, \mathrm{t}, \mathrm{NH}_{\mathrm{z}}\right), 4.4\left(3 \mathrm{H}, \mathrm{d}, \mathrm{H}_{1}\right), 4.1-3.7(17 \mathrm{H}, \mathrm{m}$, $\mathrm{H}_{5}, \mathrm{H}_{6}, \mathrm{CH}_{2} \mathrm{O}, \mathrm{H}_{6}, \mathrm{CH}_{2}$ gly), 3.1 (2H, tdd, $\left.\mathrm{C}_{2} \mathrm{NH}\right), 2.2$ (4H, m, $\left.\mathrm{CH}_{2} \mathrm{CO}\right), 2.1-1.9$ (36H, s, $\left.\mathrm{CH}_{3} \mathrm{CO}\right), 1.6-1.4\left(2 \mathrm{H}, \mathrm{m}, \mathrm{CH}_{2} \mathrm{CH}_{2} \mathrm{NH}\right), 1.2\left(16 \mathrm{H}, \mathrm{m}, \mathrm{CH}_{2}\right.$ chain). ${ }^{13} \mathrm{C} \mathrm{NMR}\left(62.86 \mathrm{MHz}, \mathrm{CDCl}_{3}\right)$ $\delta$ 170.6 (CO amide), 153.9 (CO carbamate), 137.3-128.5 (Ph), 101.9 (C anomer $\beta$ ), 71.4-59.7 $\left(\mathrm{CH}_{2} \mathrm{O}, \mathrm{CH}_{2} \mathrm{Z}, \mathrm{CH}_{2}\right.$ gly, $\mathrm{CH}$ Gal, $\mathrm{CH}_{2}$ tris $), 43.2$ (C tris), 36.9-25.4 $\left(\mathrm{CH}_{2}\right.$ chain), $21.1\left(\mathrm{CH}_{3}\right)$.

\section{Deprotection of benzyloxycarbonyl group by catalytic hydrogenation of compound 4} Compound 4 (1.02 g, $0.686 \mathrm{mmole})$ was stirred in ethanol at $0^{\circ} \mathrm{C}$. Palladium on charcoal $(60 \mathrm{mg}$ / mmoles) was added slowly to the solution. The mixture was hydrogenated for $4 \mathrm{~h}$, then filtered over celite. The filtrate was concentrated under vacuum to obtain the deprotected compound as a white powder $(0.927 \mathrm{~g}, 100 \%)$.

Compound B1. After hydrogenolysis of benzyloxycarbonyl group with hydrogen on palladium on charcoal, compound 4 (0.536 g, $0.397 \mathrm{mmole})$, decyl diisocyanate (0.042 g, $0.189 \mathrm{mmole})$ and DABCO $(10 \mathrm{mg})$ were stirred in acetonitrile $(25 \mathrm{ml})$ for $12 \mathrm{~h}$ at room temperature. The 
mixture was concentrated under vacuum, dissolved in ethyl acetate and washed with $1 \mathrm{~N} \mathrm{HCl}$, sat. $\mathrm{NaHCO}_{3}$ and dried with sodium sulfate. After concentration under vacuum the residue was directly applied at the top of Sephadex $\mathrm{LH} 20$ column $\left(\mathrm{CH}_{2} \mathrm{Cl}_{2} / \mathrm{MeOH} 1 / 1: \mathrm{v} / \mathrm{v}\right)$ to afford the pure product as a white amorphous powder $\left(0.400 \mathrm{~g}, 65 \%, \mathrm{Mp}=88-90^{\circ} \mathrm{C}\right) .[\alpha]_{D}^{20}=-8.31(\mathrm{c}, 1$, $\mathrm{CH}_{2} \mathrm{Cl}_{2}$ ). ${ }^{1} \mathrm{H}$ NMR $\left(250 \mathrm{MHz}, \mathrm{CDCl}_{3}\right) \delta 6.43(2 \mathrm{H}, \mathrm{t}, \mathrm{NH}$ gly, $6.22(2 \mathrm{H}, \mathrm{s}, \mathrm{NH}$ tris); $5.4(6 \mathrm{H}, \mathrm{dd}$, $\left.\mathrm{H}_{4}\right)$; 5.3-5.0 (16H, $\mathrm{N} \underline{\mathrm{H}}\left(\mathrm{CH}_{2}\right)_{10}, \mathrm{H}_{3}$ et $\left.\mathrm{H}_{2}\right), 4.4\left(6 \mathrm{H}, \mathrm{d}, \mathrm{H}_{1}\right), 4.2-3.6\left(34 \mathrm{H}, \mathrm{m}, \mathrm{CH}_{2} \mathrm{O}, \mathrm{H}_{5}, \mathrm{H}_{6}, \mathrm{H}_{6}\right.$ et $\mathrm{CH}_{2}$ gly), $3.1\left(8 \mathrm{H}, \mathrm{td}, \mathrm{C}_{2} \mathrm{NH}\right), 2.3\left(4 \mathrm{H}, \mathrm{t}, \mathrm{CH}_{2} \mathrm{CO}\right), 2.2-2.0\left(72 \mathrm{H}, \mathrm{s}, \mathrm{CH}_{3}\right), 1.6-1.2\left(48 \mathrm{H}, \mathrm{m}, \mathrm{CH}_{2}\right.$ chain). ${ }^{13} \mathrm{C}$ NMR (62.86 MHz, $\left.\mathrm{CDCl}_{3}\right) \delta$ 170.4-168.8 (CO), 158.3 (CO urea), $101.3\left(\mathrm{C}_{1}\right.$ anomer $\beta$ ), 70.8-59.2 ( $\underline{\mathrm{CH}}$ glycoside, $\underline{\mathrm{C}} \mathrm{H}_{2} \mathrm{O}$ gal, $\mathrm{C}_{2} \mathrm{NH}, \mathrm{CH}_{2}$ gly), 42.6 (C tris), $40.4\left(\underline{\mathrm{CH}}_{2}-\mathrm{CH}_{2} \mathrm{NH}\right)$, 34.2-30.2 $\left(\mathrm{CH}_{2} \mathrm{CO}\right), 29.6-25.5\left(\mathrm{CH}_{2}\right.$ chain $), 20.7\left(\mathrm{CH}_{3}\right)$. TOF MS ES ${ }^{+}(1918 \mathrm{~g} / \mathrm{mole}): \mathrm{m} / \mathrm{z}=$ $1942.93(\mathrm{M}+\mathrm{Na}+\mathrm{H})^{+}, 1957(\mathrm{M}+\mathrm{K})^{+}$

Compound B2. Prepared according to the above procedure starting from compound 4 ( $0.955 \mathrm{~g}$, $0.707 \mathrm{mmole})$, phenyl diisocyanate $(0.054 \mathrm{~g}, 0.336 \mathrm{mmole})$, DABCO (100 $\mathrm{mg})$ to afford compound $\mathbf{B} 3$ after purification by flash chromatography $\left(\mathrm{CH}_{2} \mathrm{Cl}_{2} / \mathrm{MeOH} 9 / 1: \mathrm{v} / \mathrm{v}\right)$ and sephadex LH $20\left(\mathrm{CH}_{2} \mathrm{Cl}_{2} / \mathrm{MeOH}: 1 / 1\right)$ as an amorphous solid $\left(0.280 \mathrm{~g}, 51 \%, \mathrm{Mp}=82.4-84^{\circ}\right.$ C). $[\alpha]_{D}^{20}=-7.1\left(\mathrm{c}, 1, \mathrm{CH}_{2} \mathrm{Cl}_{2}\right) .{ }^{1} \mathrm{H}$ NMR $\left(250 \mathrm{MHz}, \mathrm{CDCl}_{3}\right) \delta 7.23(4 \mathrm{H}, \mathrm{s}, \mathrm{Ph}), 6.4(2 \mathrm{H}, \mathrm{t}, \mathrm{NH}$ gly), $6.3\left(2 \mathrm{H}, \mathrm{s}, \mathrm{NH}\right.$ tris), $6.2\left(2 \mathrm{H}, \mathrm{s}, \mathrm{NH}\right.$ urea), $5.4\left(6 \mathrm{H}, \mathrm{dd}, \mathrm{H}_{4}\right), 5.1-5.0\left(14 \mathrm{H}, \mathrm{m}, \mathrm{N} \underline{\mathrm{H}}\left(\mathrm{CH}_{2}\right)_{10}, \mathrm{H}_{3}\right.$ et $\left.\mathrm{H}_{2}\right) 4.4\left(6 \mathrm{H}, \mathrm{d}, \mathrm{H}_{1}\right), 4.2-3.8\left(34 \mathrm{H}, \mathrm{m}, \mathrm{CH}_{2} \mathrm{O}, \mathrm{H}_{5}, \mathrm{H}_{6}, \mathrm{H}_{6}, \mathrm{CH}_{2}\right.$ gly), $3.2\left(4 \mathrm{H}, \mathrm{t}, \mathrm{C}_{2} \mathrm{NH}\right), 2.2$ (4H, t, $\left.\mathrm{CH}_{2} \mathrm{CO}\right), 2.1-1.9\left(72 \mathrm{H}, \mathrm{s}, \mathrm{CH}_{3} \mathrm{CO}\right), 1.2\left(32 \mathrm{H}, \mathrm{m}, \mathrm{CH}_{2}\right.$ chain). ${ }^{13} \mathrm{C} \mathrm{NMR}(62.86 \mathrm{MHz}$, $\left.\mathrm{CDCl}_{3}\right) \delta$ 170.4-168.9 (CO), 134.4-122.0 (Ph), 101.3 (C anomer $\left.\beta\right)$, 70.7-59.2 $\left(\mathrm{CH}_{2} \mathrm{O}\right.$ gal, $\mathrm{CH}$ glycoside, $\mathrm{CH}_{2}$ gly), 42.7 (C tris), $40.0\left(\underline{\mathrm{CH}}_{2} \mathrm{CO}\right), 36.2\left(\mathrm{CH}_{2} \mathrm{NH}\right), 30-26.7\left(\mathrm{CH}_{2}\right.$ chain $), 20.9-20.6$ $\left(\mathrm{CH}_{3}\right)$. TOF MS ES ${ }^{+}(1854 \mathrm{~g} / \mathrm{mole}): \mathrm{m} / \mathrm{z}=1878(\mathrm{M}+\mathrm{Na}+\mathrm{H})^{+}$.

Compound B3. Compound 4 (0.910g, $0.674 \mathrm{mmole})$, BOP (0.313 g, 0.707 mmole), DMAP $(0.0863 \mathrm{~g}, 0.707 \mathrm{mmole})$ and succinic anhydride $(0.033 \mathrm{~g}, 0.337 \mathrm{mmole})$ were stirred in dichloromethane dry for $12 \mathrm{~h}$ at room temperature. After concentration under vacuum the crude product was purified by flash chromatography (AcOEt / MeOH 95/5: v/v) and sephadex LH 20 $\left(\mathrm{CH}_{2} \mathrm{Cl}_{2} / \mathrm{MeOH}: 1 / 1\right)$ to afford compound $\mathbf{B 3}$ as an amorphous solid $(0.370 \mathrm{~g}, 40 \%, \mathrm{Mp}=100-$ $\left.102^{\circ} \mathrm{C}\right) .[\alpha]_{D}^{20}=-9.3\left(\mathrm{c}, 1, \mathrm{CH}_{2} \mathrm{Cl}_{2}\right) .{ }^{1} \mathrm{H}$ NMR $\left(250 \mathrm{MHz}, \mathrm{CDCl}_{3}\right) \delta 6.36(2 \mathrm{H}, \mathrm{t}, \mathrm{NH}$ amide $), 6.2$ ( $2 \mathrm{H}, \mathrm{s}, \mathrm{NH}$ tris), $5.3\left(6 \mathrm{H}, \mathrm{dd}, \mathrm{H}_{4}\right), 5.0\left(14 \mathrm{H}, \mathrm{m}, \mathrm{H}_{3}, \mathrm{H}_{2}, \mathrm{~N} \underline{\mathrm{H}}\right.$ carbamate), $4.4\left(6 \mathrm{H}, \mathrm{d}, \mathrm{H}_{1}\right), 4.1-3.7$ (30H, m, $\mathrm{CH}_{2} \mathrm{O}, \mathrm{H}_{5}, \mathrm{H}_{6}$ et $\mathrm{H}_{6}, \mathrm{CH}_{2} \mathrm{gly}$ ), 3.2 (4H, t dd, $\mathrm{C}_{2} \mathrm{NH}$ ), 2.4 (4H, t, $\mathrm{CH}_{2}$ succinate), 2.2 (4H, t, $\left.\mathrm{CH}_{2} \mathrm{CO}\right), 2.1-1.9\left(72 \mathrm{H}, \mathrm{m}, \mathrm{CH}_{3}\right), 1.5-1.2\left(32 \mathrm{H}, \mathrm{m}, \mathrm{CH}_{2}\right.$ chain). ${ }^{13} \mathrm{C}$ NMR $(62.86 \mathrm{MHz}$, $\left.\mathrm{CDCl}_{3}\right) \delta$ 170.5-169.0 (C=O), $101.5(\mathrm{C}$ anomer $\beta)$, 70.9-59.4 $\left(\mathrm{CH}_{2}\right.$ gly, $\mathrm{CH}_{2} \mathrm{Ogal}, \mathrm{CHO}$ glycoside), 39.7 (C tris), $36.5\left(\mathrm{CH}_{2} \mathrm{NH}\right), 32.1\left(\mathrm{CH}_{2} \mathrm{CO}\right)$, 29.6-25.6 $\left(\mathrm{CH}_{2}\right.$ chain), 20.9-20.6 $\left(\mathrm{CH}_{3}\right)$. TOF MS ES ${ }^{+}(1776 \mathrm{~g} / \mathrm{mole}): \mathrm{m} / \mathrm{z}=1799.74(\mathrm{M}+\mathrm{Na})^{+}, 1800.61(\mathrm{M}+\mathrm{Na}+\mathrm{H})^{+}$.

Compound 5. Ethyl undecenoate $(9.6 \mathrm{ml}, 39.7$ mmoles) and diiodo perfluorohexane (2 g, 3.61 mmoles) were stirred under argon for $15 \mathrm{~min}$ at $90{ }^{\circ} \mathrm{C}$. AIBN (0.018 g, 0.109 mmoles) was added and the mixture stirred for $12 \mathrm{~h}$ at $90{ }^{\circ} \mathrm{C}$ in the dark.Some excess ester was eliminated under high vacuum and the crude product was purified by flash-chromatography (hexane / ethyle acetate $9 / 1: \mathrm{v} / \mathrm{v})$ to afford compound 5 as a colourless oil $(1.8 \mathrm{~g}, 51 \%)$. ${ }^{1} \mathrm{H}$ NMR $(250 \mathrm{MHz}$, $\left.\mathrm{CDCl}_{3}\right) \delta 4.3(2 \mathrm{H}, \mathrm{tt}, \mathrm{CH}-\mathrm{I}), 4.1\left(4 \mathrm{H}, \mathrm{q}, \mathrm{C}_{2} \mathrm{CH}_{3}\right), 2.8\left(4 \mathrm{H}, \mathrm{m}, \mathrm{CH}_{2} \mathrm{CF}_{2}\right), 2.3\left(4 \mathrm{H}, \mathrm{t}, \mathrm{CH}_{2} \mathrm{CO}\right)$, 
1.8-1.7 (4H, td, ICH-C $\left.\underline{H}_{2}-\left(\mathrm{CH}_{2}\right)_{6}\right), 1.6-1.3\left(30 \mathrm{H}, \mathrm{m}, \mathrm{CH}_{2}\right.$ chain, $\left.\mathrm{CH}_{3}\right) .{ }^{19} \mathrm{~F} \mathrm{NMR}(235 \mathrm{MHz}$, $\left.\mathrm{CDCl}_{3}\right) \delta-113.3$ (4F, dd, $\mathrm{CF}_{2}-\mathrm{CH}_{2}$ ), -121.9 (4F, s, $\left.\mathrm{CH}_{2} \mathrm{CF}_{2} \mathrm{CF}_{2}\right),-123.9$ (4F, s, $\mathrm{CH}_{2} \mathrm{CF}_{2} \mathrm{CF}_{2} \mathrm{CF}_{2}$ ). ${ }^{13} \mathrm{C} \mathrm{NMR}\left(62.86 \mathrm{MHz}, \mathrm{CDCl}_{3}\right) \delta 170.1(\mathrm{CO}), 120.3-110.8\left(\mathrm{CF}_{2}\right), 65.8\left(\mathrm{CH}_{2} \mathrm{O}\right), 60.3\left(\mathrm{CH}_{2} \mathrm{CHI}\right)$, $40.5(\underline{\mathrm{CHI}}), 36.4\left(\underline{\mathrm{CH}}_{2} \mathrm{CO}\right), 34.0\left(\mathrm{ICHCH}_{2}\left(\mathrm{CH}_{2}\right)_{7}\right), 29.8-26.0\left(\mathrm{CH}_{2}\right.$ chain $), 20.6\left(\mathrm{CH}_{3}\right)$.

Compound 6. Compound 5 (1.8 g, 1.84 mmoles) was stirred in $1.5 \mathrm{~N} \mathrm{KOH-methanol} \mathrm{mixture}$ $(50 \mathrm{ml})$ for $12 \mathrm{~h}$ at room temperature. The mixture was acidified with $3 \mathrm{~N} \mathrm{HCl}(\mathrm{pH}=2)$ and concentrated under vacuum. The crude product was dissolved in ethyl acetate, washed with $1 \mathrm{~N}$ $\mathrm{HCl}$ and sat $\mathrm{Na}_{2} \mathrm{~S}_{2} \mathrm{O}_{4}$ and dried with sodium sulfate. The solvent was removed under vacuum and the compound 6 was obtained as a colourless oil $(0.910 \mathrm{~g}, 76 \%)$. ${ }^{1} \mathrm{H} \mathrm{NMR}\left(250 \mathrm{MHz}, \mathrm{CDCl}_{3}\right)$ $\delta$ 6.4-6.0 (1.5H, 0.5H, m, $\mathrm{CHC}_{6} \mathrm{~F}_{12}$ trans and cis respectively), 5.6-5.3 (2H, m, $\left.\mathrm{CH}=\mathrm{CHC}_{6} \mathrm{~F}_{12}\right)$, 2.3-2.0 (8H, m, $\left.\mathrm{CH}_{2} \mathrm{CO}, \mathrm{CH}_{2} \mathrm{CH}=\mathrm{CH}\right), 1.6-1.3$ (24H, m, $\mathrm{CH}_{2}$ chain). ${ }^{19} \mathrm{~F} \mathrm{NMR}(235 \mathrm{MHz}$, $\left.\mathrm{CDCl}_{3}\right) \delta-108.68\left(1 \mathrm{~F}, \mathrm{CH}=\mathrm{CHCF}_{2}\right.$ cis), $-113.58\left(3 \mathrm{~F}, \mathrm{CH}=\mathrm{CHCF}_{2}\right.$ trans), -123.81 (4F, $\mathrm{CF}_{2}-$ $\left.\mathrm{CF}_{2} \mathrm{CH}\right),-126.08$ (4F, $\left.\mathrm{CF}_{2} \mathrm{CF}_{2} \mathrm{CF}_{2} \mathrm{CH}\right) .{ }^{13} \mathrm{C} \mathrm{NMR}\left(62.86 \mathrm{MHz}, \mathrm{CDCl}_{3}\right) \delta 172.8(\mathrm{CO}), 142.15$ $\left(\mathrm{CF}_{2} \underline{\mathrm{CH}}=\mathrm{CH}\right), 139.1\left(\mathrm{CF}_{2} \mathrm{CH}=\underline{\mathrm{CH}}\right), 120.3-110.8\left(\mathrm{CF}_{2}\right), 34.49\left(\mathrm{CH}_{2} \mathrm{CO}\right), 32.4\left(\mathrm{CH}_{2} \mathrm{CH}=\mathrm{CH}\right)$, 29.6-21.1 ( $\mathrm{CH}_{2}$ chain).

Compound 7. Compound $6(0.910 \mathrm{~g}, 1.37 \mathrm{mmole})$ was dissolved in toluene at $5^{\circ} \mathrm{C}$. Palladium on charcoal (60 $\mathrm{mg} / \mathrm{mmole})$ was added slowly under vigorous stirring. The mixture was hydrogenated ( $\mathrm{P}=5$ bars) for $2 \mathrm{~h}$. Palladium was removed by filtration over celite. The filtrate was concentrated under vacuum to afford compound 7 as a white powder $(0.6 \mathrm{~g}, 66 \%)$. ${ }^{1} \mathrm{H} \mathrm{NMR}$ (250 MHz, DMSOd6) $\delta$ 2.3-2.2 (8H, m, $\left.\underline{\mathrm{C}}_{2} \mathrm{CF}_{2}, \mathrm{CH}_{2} \mathrm{CO}\right), 1.56-1.53\left(4 \mathrm{H}, \mathrm{t}, \mathrm{C}_{2} \mathrm{CH}_{2} \mathrm{CF}_{2}\right), 1.3$ (28H, m, $\mathrm{CH}_{2}$ chain). ${ }^{19} \mathrm{~F}$ NMR (235 MHz, DMSOd6) $\delta-123.1\left(\mathrm{CH}_{2} \mathrm{CF}_{2}\right),-121.4\left(\mathrm{CF}_{2} \mathrm{CF}_{2} \mathrm{CH}_{2}\right)$, $122.8\left(\mathrm{CF}_{2} \mathrm{CF}_{2} \mathrm{CF}_{2} \mathrm{CH}_{2}\right) .{ }^{13} \mathrm{C} \mathrm{NMR}(62.86 \mathrm{MHz}, \mathrm{DMSOd} 6) \delta 174.0(\mathrm{CO}), 120-110\left(\mathrm{CF}_{2}\right), 54.86$ $\left(\mathrm{CH}_{2} \mathrm{CF}_{2}\right), 33.62\left(\mathrm{CH}_{2} \mathrm{CO}\right), 29.8-24\left(\mathrm{CH}_{2}\right.$ chain $)$.

Compound B4. Compound 7 (0.3g, 0.447 mmole), compound 3 (1.099 g, $0.941 \mathrm{mmole})$ DCC (0.243 g, 1.177 mmole) and HOBT (100 mg) were stirred in DMF for $12 \mathrm{~h}$ at room temperature. DCU was removed by filtration. The filtrate was concentrated under vacuum and the crude product was dissolved in ethyl acetate. The organic layer was washed with sat $\mathrm{NaHCO}_{3}$, water and dried over sodium sulfate. The solvent was eliminated under vacuum and the crude product flash-chromatographied over silica-gel (ethyle acetate/hexane $96 / 4: \mathrm{v} / \mathrm{v}$ then ethyle acetate) to afford the pure compound $\mathbf{B} 4$ as a white powder $\left(600 \mathrm{mg}, 43 \%, \mathrm{Mp}=95-97^{\circ} \mathrm{C}\right) .[\alpha]_{D}^{20}=-10.7$ (c, 1, $\mathrm{CH}_{2} \mathrm{Cl}_{2}$ ). ${ }^{1} \mathrm{H}$ NMR (250 MHz, $\left.\mathrm{CDCl}_{3}\right) \delta 6.3(2 \mathrm{H}, \mathrm{t}, \mathrm{NH}$ gly), $6.2(2 \mathrm{H}, \mathrm{s}, \mathrm{NH}$ tris), 5.4 (6H, dd, $\left.\mathrm{H}_{4}\right)$, 5.1-5.0 (12H, m, $\mathrm{H}_{3}$ et $\left.\mathrm{H}_{2}\right), 4.4\left(6 \mathrm{H}, \mathrm{d}, \mathrm{H}_{1}\right), 4.2-3.7\left(34 \mathrm{H}, \mathrm{m}, \mathrm{CH}_{2} \mathrm{Ogal}, \mathrm{CH}_{2} \mathrm{gly}, \mathrm{H}_{5}, \mathrm{H}_{6}\right.$ et $\mathrm{H}_{6}$ ), 2.25-2.0 (80H, m, $\left.\mathrm{CH}_{3}, \mathrm{CH}_{2} \mathrm{CO}, \mathrm{CH}_{2} \mathrm{CF}_{2}\right)$, 1.6-1.3 (32H, m, $\mathrm{CH}_{2}$ chain). ${ }^{19} \mathrm{~F} \mathrm{NMR} \mathrm{(235}$ $\left.\mathrm{MHz}, \mathrm{CDCl}_{3}\right) \delta-114.7\left(4 \mathrm{~F}, \mathrm{CF}_{2} \mathrm{CH}_{2}\right),-122.16\left(4 \mathrm{~F}, \mathrm{CF}_{2} \mathrm{CF}_{2} \mathrm{CH}_{2}\right),-124.0\left(\mathrm{CF}_{2} \mathrm{CF}_{2} \mathrm{CF}_{2} \mathrm{CH}_{2}\right) .{ }^{13} \mathrm{C}$ NMR (62.86 MHz, $\left.\mathrm{CDCl}_{3}\right) \delta 170.5-169(\mathrm{CO}), 136.8-126.2\left(\mathrm{CF}_{2}\right), 101.5\left(\mathrm{C}_{1}\right.$ anomer $\left.\beta\right), 70.9-$ $59.4\left(\mathrm{CH}_{2} \mathrm{gly}, \mathrm{CH}_{2} \mathrm{Ogal}, \mathrm{CH}\right.$ glycoside), 42.8 (C tris), $36.5\left(\underline{\mathrm{CH}}_{2} \mathrm{CO}\right), 29.5-25.7\left(\mathrm{CH}_{2}\right.$ chain), 20.9-20.7 $\left(\mathrm{CH}_{3}\right)$. TOF MS ES ${ }^{+}(1962 \mathrm{~g} / \mathrm{mole}): \mathrm{m} / \mathrm{z}=1985.73(\mathrm{M}+\mathrm{Na})^{+}, 1986.66(\mathrm{M}+\mathrm{Na}+\mathrm{H})^{+}$.

Deacetylation of compounds A1-A3 and B1-B4. Type-A and -B compounds were de-Oacetylated overnight by Zemplen method with a catalytic amount of sodium methylate in methanol (40 ml). After treatment with a $\mathrm{H}^{+}$-type resin (Amberlite IRC 50) followed by filtration 
and evaporation of the solvent, pure type-A and $\mathbf{B}$ compounds were isolated in quantitative yield after filtration on sephadex G 25 column with water as eluent.

\section{References}

1. Fuoss, R. M.; Edelson, D. J. J. Am. Chem. Soc. 1951, 78, 269.

2. Woese, C.R.; Kandler, O; Wheelis, M.L. Proc. Natl. Acad. Sci. USA 1990, 87, 45.

3. The archaebacteria : biochemistry and biotechnology, Dawson, M.J.; Hough, D.W.; Lunt, G.G., Eds ; Portland Press: London and Chapel Hill, 1992.

4. Eguchi, T.; Arakawa, K.; Terachi, T.; Kakinuma, K. J. Org. Chem. 1997, 62, 1924.

5. Conlan, J. W.; Krishnan, L.; Willick, G. E.; Patel, G. B.; Sprott, G. D. Vaccine 2001, 19, 3509 .

6. (a) Fuhrhop, J. H.; Wang, T. Chem. Rev. 2004, 104, 2901. (b) Benvegnu, T.; Brard, M.; Plusquellec, D. Curr. Opin. Colloid Interface Sci. 2004, 8, 469.

7. Shimizu, T.; Iwaura, R.; Masuda, M.; Hanada, T.; Yase, K. J. Am. Chem. Soc. 2001, 123, 5947.

8. Kogiso, M.; Ohnisi, S.; Yase, K.; Masuda, M.,; Shimizu, T. Langmuir 1998, 14, 4978.

9. Kogiso, M.; Okada, Y.; Hanada, T.; Yase, K.; Shimizu, T. Biochim. Biophys. Acta 2000 1475, 346 .

10. Nakazawa, I.; Masuda, M.; Okada, Y.; Hanada, T.; Yose, K.; Asai, M.; Shimizu, T. Langmuir 1999, 15, 4757.

11. Schneider, J.; Messerschmidt, C.; Shulz, A.; Gnade, M.; Schade, B.; Luger, P.; Bombicz, P.; Hubert, V.; Fuhrhop, J.H. Langmuir 2000, 16, 8575.

12. Wang, X.; Shen, Y.; Pan, Y.; Liang, Y. Langmuir 2001, 17, 3162.

13. Shimizu,T.; M. Masuda, J. Am. Chem. Soc. 1997, 119, 2812.

14. Munoz, S.; Mallen, J.; Nakano, A.; Chen, Z.; Gay, I.; Echegoyen, L.; Gokel, G.W. J. Am. Chem. Soc. 1993, 115, 1705.

15. Brisset, F.; Garelli-Calvet, R.; Azema, J.; Chebli, C.; Rico-Lattes, I.; Lattes, A. New J. Chem. 1996, 20, 595.

16. Polidori, A.; Pucci, B.; Zarif, L.; Lacombe, J. M.; Riess, J. G.; Pavia, A. A. Chem. Phys. Lipids 1995, 77, 225.

17. Brace, N. J. Org. Chem. 1962, 27, 4491.

18. Menger, F. M.; Littau, C. A. J. Am. Chem. Soc. 1993, 115, 10083.

19. Kalyanasundaram, K.; Thomas, J. K. J. Am. Chem. Soc. 1977, 99, 2039.

20. Mixed surfactant systems Funasaki, N., In Ogino, K.; Abe, M. Eds, from Surfactant Science Series 46, Dekker: New York, 1993, Ch. 5, p145.

21. Polidori, A.; Pucci, B.; Maurizis, J. C.; Pavia, A. A. New J. Chem. 1994, 18, 839.

22. Guilbot, J.; Benvegnu, T.; Legros, N.; Plusquellec, D. Langmuir 2001, 17, 613.

23. Guedj, C.; Pucci, B.; Zarif, L.; Coulomb, C.; Riess, J.G.; Pavia, A. A. Chem. Phys. Lipids 1994, 72, 153. 